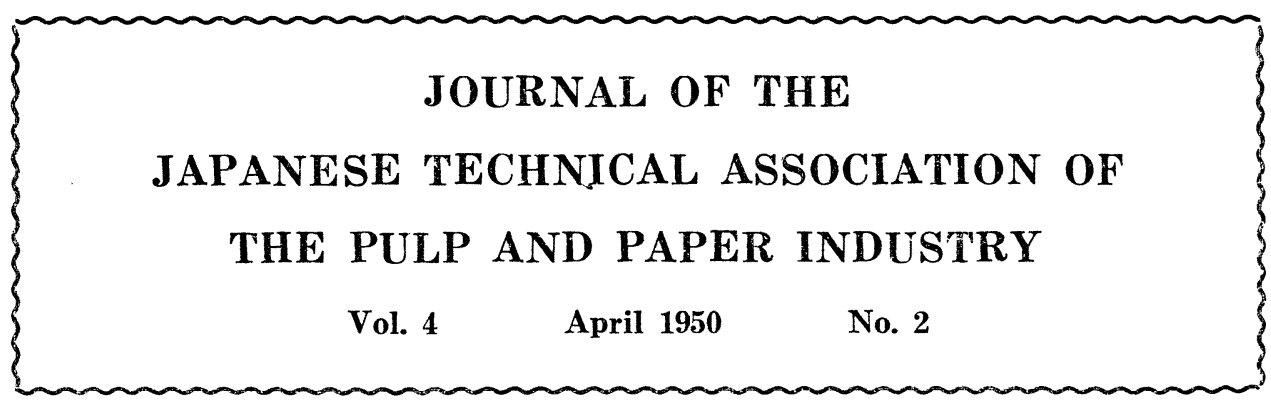

\title{
WASTE IN THE PULP AND PAPER MIIL
}

\section{by Frank J. Spinar (1) member JTAPPI}

Recently I had the opportunity of addressing the meeting of Japanese foresters regarding the pulpwood situation in Japan, its future outlook, and the measures that must be taken to remedy this situation. I mentioned to them that in my opinion the pulpwood situation had no simple solution but rather had to be divided into two programs, a short term program and a long term program. The long term program principally of consists of reforestation which is a problem for the foresters, but the short term program is principally the Engineer's concern.

Demands for timber and timber products for the rehabilitation of Japan continue to be great. Timber products are needed for housing, which continues to be in short supply. Railroads need much timber for their maintenance and rehabilitation as does the communications system. Proposed plans for the electric development are going to require a great amount of timber products. The road rehabilitation program in itself is going to require over $5,000,000 \mathrm{koku}$ of timber during the coming year. I mention these things in order to point out that pulpwood supply cannot be expected to increase, rather the industry is going to have to do more with what it has.

The engineers must concern themselves immediately with the short range program which consists of (1) of getting more for less. In other words, more pulp will have to be produced from the same amount of pulpwood. This means that the industry will have to further adopt high yield pulping methods and to reduce waste to get the most possible from what pulpwood it has. I estimate that this waste alone amounts to $12 \%$ of the pulpwood entering the mills in some cases. (2) the industry will have to increase its utilization of broadleaved species which are not in such short supply. Broadleaved species when properly processed and used, make good paper, and (3) a greater utilization of agricultural residual straws for pulp and paper must be practiced in order to conserve and extend the pulpwood resource.

In this paper I would like to deal especially with the waste that occurs at the mills. I mentioned that in some cases this amounts to $12 \%$ of the pulpwood entering the mill. Just consider, $12 \%$ of the pulpwood being wasted means that of your present $81 / 2$ million koku of pulpwood consumed this year approximately 1,000,000 koku are being

(1) Pulp and Paper Branch, Natural Resources Section, GHQ-SCAP. This article is published with the permisson of the Chief, Natural Resources Section. 
wasted. In my opinion much of it could be saved.

The waste occurs principally at four places in the pulp mills. The first place is when the pulp logs are cut into short length prior to chipping. The second place is at the chipper. The third is in screening rejects; and the fourth place is in the white water losses.

Waste occurs everytime a saw cuts thru a log. The saw-dust cannot be pulped. In the mills I notice pulpwood logs being cut into 2 to 3 foot lengths when the chippers can handle 10 to 12 foot logs. Unless the logs are being prepared for grinders they should be as long as can be handled conveniently. Only a little saw-dust is produced each time but after a week, a month or a year this is a considerable amount and represents many koku of pulpwood.

I find that the usual amount of chipper waste is between 5 and $8 \%$ of the pulpwood coming into the mill. This occurs as fines or oversized pieces which are rejected by the chip screen. Some of these rejects are caused by chipping non-uniform sized pulpwood, some of it is due to faulty chippers, and some is due to faulty installations. I have not seen any attempt to reprocess the over-sized chips which could easily be done and no effort has been made to use the chipper fines. Reusing the chipper fines presents a problem but possibly this could be done by separately cooking these chipper fines in a rotating globe digester and then processing as usual. The principal reason for not including chipper fines at present is due to the fact that because of their small size, they would pack the digesters, prevent circulation and would be overcooked in the cooking process.

The third cause of waste is a large amount of screening rejects. In general the chips accepted by the chip screen are not of uniform size. This results in the lack of penetration of the cooking liquor into the large size chips and in undercooking them causing a large screening reject content.

The fourth cause of waste I mentioned was in white water losses which are in some cases quite high. One of the mills has succeeded in reducing its white water losses from ten to 3 percent. But when you stop to consider that three percent white water losses means a waste of six percent of the pulpwood, this white water loss is still too high. This is especially so when you consider that this pulp is pulp which has already been paid for and requires no further processing in order to make it usable for paper production.

I believe that reduction in waste and better waste utilization is one of the biggest technical problems confronting the industry. It is one of those things that is with us all the time and must be considered always. I believe immediate consideration must be given to solve this problem. I do not believe there is more important research going on in Japan at present. This problem can be solved and it must be solved soon. The research staffs are adequate as is this equipment and I am sure that if this problem is given consideration it will not be long before this waste is reduced considerably.

One big step toward solving the waste problem is to know just what it is and how much it amounts to. I suggest that the engineers make tests in your mills and find out just how much waste is occurring at the saws and chippers, what the amount of screening rejects is at present, exactly what your white water losses are and then I believe that you would see that considerable savings by waste reduction could be effected. 